\title{
Influence of temperature shifts on the onset and development of red sea bream iridoviral disease in rock bream Oplegnathus fasciatus
}

\author{
Lyu Jin Jun ${ }^{1}$, Joon Bum Jeong ${ }^{2}$, Ju Heon Kim ${ }^{1}$, Jeong Hee Nam ${ }^{1}$, Ki Won Shin ${ }^{1}$, \\ Joong Kyun Kim ${ }^{3}$, Ju-Chan Kang ${ }^{1}$, Hyun Do Jeong ${ }^{1, *}$
}

${ }^{1}$ Department of Aquatic Life Medicine, and ${ }^{3}$ Department of Biotechnology and Bioengineering, Pukyong National University, Daeyeon 3 dong, Nam-gu, Busan 608-737, South Korea

${ }^{2}$ Faculty of Applied Marine Science, College of Ocean Science, Cheju National University, Ara 1 dong,

Jeju-do 690-756, South Korea

\begin{abstract}
The effects of various water temperature treatments on the development of red sea bream iridovirus disease (RSIVD) in rock bream Oplegnathus fasciatus challenged with iridovirus Sachun (IVS-1) were determined by measuring the mortality and the viral concentration in the spleen of infected fish. Experimental infections of rock bream with IVS-1 at water temperatures of 18, 21, and $25^{\circ} \mathrm{C}$ resulted in a cumulative mortality of $100 \%$, but infections at $13^{\circ} \mathrm{C}$ resulted in $0 \%$ mortality, even after $45 \mathrm{~d}$. The disease progressed more rapidly at higher water temperatures; at 25, 21, and $18^{\circ} \mathrm{C}$, the mean numbers of days until death were 17,20 , and $30 \mathrm{~d}$, respectively. When the water temperature for fish infected with iridovirus by intramuscular injection was shifted from 13 to $25^{\circ} \mathrm{C}$, the cumulative mortality reached $100 \%$, with rapid onset of the disease, independent of the time at which the temperature was shifted, i.e. 7, 14, or $30 \mathrm{~d}$ after injection at $13^{\circ} \mathrm{C}$. Real-time PCR data revealed that the viral genome copy number in the spleen of rock bream maintained at $13^{\circ} \mathrm{C}$ increased with time, suggesting the occurrence of viral replication even at $13^{\circ} \mathrm{C}$. In the reverse experiment, when the water temperature for fish that were infected at a higher temperature was shifted to $13^{\circ} \mathrm{C}$, 3 or $7 \mathrm{~d}$ after injection at $25^{\circ} \mathrm{C}$, the fish showed $100 \%$ cumulative mortality, although the mean number of days until death was higher than that observed for fish maintained at a constant temperature of $25^{\circ} \mathrm{C}$. The viral DNA concentration in the spleen of rock bream that had been shifted down to $13^{\circ} \mathrm{C}$, 3 or $7 \mathrm{~d}$ after injection at $25^{\circ} \mathrm{C}$, was not suppressed, but increased and eventually reached levels sufficient to induce mortality at $13^{\circ} \mathrm{C}$. However, the level of viral genome copy numbers in the spleen of dead fish at $25^{\circ} \mathrm{C}$, regardless of whether those fish were held at a constant temperature of $25^{\circ} \mathrm{C}$ or shifted up from $13^{\circ} \mathrm{C}$, appeared to be greater than the level found in the dead fish shifted down to $13^{\circ} \mathrm{C}$ after inoculation at $25^{\circ} \mathrm{C}$.
\end{abstract}

KEY WORDS: Temperature shift · Iridovirus · Oplegnathus fasciatus $\cdot$ Quantification

Resale or republication not permitted without written consent of the publisher

\section{INTRODUCTION}

The International Committee on the Taxonomy of Viruses (ICTV) currently recognizes 5 genera within the family Iridoviridae: Iridovirus, Chloriridovirus, Ranavirus, Lymphocystivirus, and Megalocytivirus. The latter 3 contain taxa that infect finfish, including Megalocytivirus, which has only been identified recently (Chinchar et al. 2005). Infectious spleen and kidney necrosis virus (ISKNV), isolated from mandarinfish
Siniperca chuatsi in China (He et al. 2001), was selected as the type species of the genus Megalocytivirus.

Iridoviral epizootic diseases have been reported in a number of marine fish species that are of importance to the aquaculture industry (Jung \& Oh 2000, He et al. 2001, Chen et al. 2003), and previous studies indicate that Megalocytivirus has a broad host range (Kawakami \& Nakajima 2002, Do et al. 2004). Previously, we have also reported a high frequency of clinical/sub- 
clinical infections of iridovirus (IVS-1) in various cultured marine fish, including market-size adults and juveniles (Jeong et al. 2006). In addition, various ornamental fish are susceptible to diseases caused by Megalocytivirus, for example, pearl gourami Trichogaster leeri iridovirus (PGIV-1) (Imajoh et al. 2007, Jeong et al. 2008). The histopathology of fish affected by iridoviruses is characterized by hypertrophy of infected cells in the spleen, kidney, and cranial connective tissue, as well as diffuse necrosis in the hematopoietic tissues of the kidney and spleen. Since it has been demonstrated that Megalocytivirus does not reproducibly multiply in some fish cell lines (He et al. 2002), diagnosis is sometimes reliant on histopathology, and PCR (polymerase chain reaction) tests.

Environmental temperature influences the physiology of poikilotherms, including metabolism, behavior, and immunological processes. For example, allograft rejection in newts is delayed significantly at temperatures $<23^{\circ} \mathrm{C}$ (Cohen 1966). In cell culture, the Ambystoma tigrinum virus (ATV) can multiply at a temperature range between 15 and $31^{\circ} \mathrm{C}$ (Jancovich 1999), which is very close to the reported preferred temperature range of the salamander Ambystoma tigrinum (Lucas \& Reynolds 1967). However, differences in virus numbers present in the tissue of salamanders that died at different water temperatures may help to elucidate temperature-dependent interactions between the salamander immune system and viral multiplication (Rojas et al. 2005). In a study of spring viremia of carp (SVC; Ahne 1984), the author suggested that water temperature determines whether infection of carp with the SVC virus results in disease/mortality or survival/development of protective immunity. In the Koi herpes virus (KHV) disease, shifting the water temperature for KHVexposed fish from 13 to $23^{\circ} \mathrm{C}$ resulted in the rapid onset of mortality, suggesting that water temperature was the principal environmental factor influencing the onset and severity of disease (Gilad et al. 2003). However, little information is available regarding the influence of water temperature on red sea bream iridovirus disease (RSIVD), the most prevalent iridoviral disease in marine aquaculture farms. Moreover, iridovirus replication, the progression of the disease, and quantitative comparisons of viral concentrations in infected fish at different water temperatures have not been systematically studied.

Here we investigated cumulative mortality and iridovirus accumulation over time in rock bream, following shifts in water temperature in an attempt to determine whether or not infection at seasonal low-risk periods may lead to high mortalities when warmer water temperatures occur in summer, facilitating rapid viral replication.

\section{MATERIALS AND METHODS}

Fish. Rock bream Oplegnathus fasciatus $(8.0 \pm 1.0 \mathrm{~g})$ were obtained from a marine fish farm located on the southern coast of Korea. Seawater temperature at the time of sampling was 16 to $18^{\circ} \mathrm{C}$. After transfer to the laboratory, the fish were kept in $40 \mathrm{l}$ tanks filled with seawater at $21^{\circ} \mathrm{C}$. The water was changed 3 times per day. After 3 wk of acclimation, 10 randomly selected experimental fish were anesthetized with MS-222 (Sigma) and confirmed to be free of iridovirus in the spleen using 2-step PCR with the primer sets KE1F/KE1R and KE2F/KE2R (Table 1).

Virus preparation. The virus used in the present study was originally isolated from farmed rock bream $(90 \pm 11.0 \mathrm{~g})$ infected with IVS-1 in 2006 (Jeong et al. 2006). Identification of IVS-1 was confirmed according to the previous description by Jeong et al. (2006). Homogenates were prepared from the spleens of rock bream experimentally infected with IVS-1 by intramuscular injection. Briefly, under anesthesia (MS-222), splenic tissue was removed from 10 fish at the moribund stage and homogenized in $20 \mathrm{vol}$ of phosphatebuffered saline (PBS; $0.1 \mathrm{M}, \mathrm{pH}$ 7.2) in a tube with a fitted pestle (Sigma-Aldrich), and then centrifuged at $3000 \times g$ for $5 \mathrm{~min}$. The supernatant was filtered through a $0.45 \mu \mathrm{m}$ membrane to create $50 \mu \mathrm{l}$ aliquots that were then stored at $-80^{\circ} \mathrm{C}$ until use. Splenic

Table 1. PCR primers used in the present study. Expected size based on the nucleotide sequence of an iridovirus-1 isolate

\begin{tabular}{|lllclll|}
\hline Genomic region & Primer & $\begin{array}{l}\text { Oligonucleotide sequence } \\
\text { (5' to 3' direction) }\end{array}$ & $\begin{array}{c}\text { Expected } \\
\text { size }\end{array}$ & Object & $\begin{array}{l}\text { Accession } \\
\text { number }\end{array}$ & Source \\
\hline ORF-2 & KE1F & AAATGGCTCTTTGGAGTGTC & $939 \mathrm{bp}$ & Primary PCR & AY628698 & Jeong et al. (2003) \\
& KE1R & AAGAATCCATCGGTATTATG & & & & \\
& KE2F & GGGTCGCCTGGTATGTAC & $554 \mathrm{bp}$ & Nested PCR & & \\
KE2R & CATCGAGGCACTCTTCGC & & & Present study \\
\hline MCP & MC1F & GAGGTGCGCATCCACTTC & CAAGATGATTGCATGCG & & Real-time PCR & AF371960 \\
& & & & & \\
\hline
\end{tabular}


homogenate from diseased fish, rather than supernatants from infected cell cultures, was used as inoculum, due to a loss of infectious iridovirus following cell culture passage.

Mortality in different water temperatures. To determine cumulative mortality rates of IVS-1-infected rock bream at 4 different water temperatures, a splenic homogenate from iridovirus-infected fish $\left(10 \mu \mathrm{g} \mathrm{fish}^{-1}\right)$ and PBS as a negative control were injected into rock bream $(8.0 \pm 1.0 \mathrm{~g})$ intramuscularly; the fish were then maintained at $13,18,21$, or $25^{\circ} \mathrm{C}(15$ fish at each temperature).

To determine cumulative mortality with interim sampling in temperature-shift experiments, approximately 250 rock bream, from the same group as above, were divided into 7 groups containing 30 fish in 601 tanks equipped with $2 \mathrm{~kW}$ electric heaters set at $21^{\circ} \mathrm{C}$. The fish in each of these tanks were further divided into 2 compartments created by plastic netting. After acclimation to the desired water temperatures $(13,18,21$, and $25^{\circ} \mathrm{C}$ ) for $1 \mathrm{wk}$ by lowering or increasing the water temperature in increments of $3^{\circ} \mathrm{C} \mathrm{d}^{-1}$, fish were inoculated intramuscularly with $0.1 \mathrm{ml}$ filtrate of the IVS-1infected tissue homogenates (corresponding to $2 \times 10^{6}$ viral genome copy number per fish). Water temperature shifts $\left(13\right.$ to $25^{\circ} \mathrm{C}$ at 7,14 , or $30 \mathrm{~d}$ post-injection or 25 to $13^{\circ} \mathrm{C}$ at 3 or $7 \mathrm{~d}$ post-injection) were accomplished in increments of $1^{\circ} \mathrm{C} \mathrm{h}^{-1}$ until the desired temperature was reached. Separate negative controls with PBS injection for each temperature-shift trial were not included, due to a lack of holding space. Instead, 10 fish whose water temperatures were shifted up to $25^{\circ} \mathrm{C}$ (or down to $13^{\circ} \mathrm{C}$ ) following 0 and 7 (or 0 and 3 ) d postinjection of PBS at $13^{\circ} \mathrm{C}$ (or $25^{\circ} \mathrm{C}$ ), respectively, were used as negative controls. All dead fish were collected on a daily basis, and the iridovirus infection was confirmed by PCR using the primer set KE2F/KE2R (Table 1), and by examining spleen imprints on glass slides stained by hematoxylin-eosin for the presence of enlarged cells using light microscopy. Interim sampling of 3 fish for analysis of viral concentration in the infected spleen during the progress of the disease under different conditions was performed. Fish used for interim sampling came from the group on 1 side of each of the 7 tanks that were divided into 2 compartments by plastic netting. The mean number of days until death was calculated using the sum of the number of days until death for each individual fish in a group divided by the total number of dead fish in that group. There were 2 replicate aquaria for each experimental group.

PCR. Total genomic DNA was extracted from the spleens of rock bream using an AccuPrep Genomic DNA Extraction Kit (Bioneer) and dissolved in distilled water $\left(100 \mu \mathrm{g} \mathrm{ml}^{-1}\right)$. Single-step PCR was carried out in a $50 \mu$ l reaction mixture containing $0.5 \mu$ of genomic DNA, 10 mM Tris- $\mathrm{HCl}$ ( $\mathrm{pH} 8.3$ ), $50 \mathrm{mM} \mathrm{KCl}, 1.5 \mathrm{mM}$ $\mathrm{MgCl}_{2}, 0.001 \%$ w/v gelatin, $0.5 \%$ Tween-20, $200 \mu \mathrm{M}$ of each dNTP, $1 \mu \mathrm{M}$ of each single-step PCR primer (Table 1), and 1.25 U of AmpliTaq DNA Polymerase (PE Applied Biosystems) using a Perkin-Elmer 2400 thermal cycler. After 2 min of initial denaturation at $95^{\circ} \mathrm{C}$, the mixtures were incubated for 30 cycles at $95^{\circ} \mathrm{C}$ for $30 \mathrm{~s}, 55^{\circ} \mathrm{C}$ for $30 \mathrm{~s}$, and $72^{\circ} \mathrm{C}$ for $30 \mathrm{~s}$, followed by a final extension at $72^{\circ} \mathrm{C}$ for $7 \mathrm{~min}$. For 2 -step PCR, the above conditions were used, except that in the second round of amplification, $0.5 \mu$ l of the reaction mixture from the first round was used as the template and the primers used were designed to anneal within the amplicons from the first round. The amplified products were analyzed by $1 \%$ agarose gel electrophoresis.

Real-time PCR. Total genomic DNA was extracted from homogenates of a known weight of experimental rock bream spleen using an AccuPrep Genomic DNA Extraction Kit (Bioneer), and quantified using LightCycler 480 SYBR Green I Master (Roche) according to the manufacturer's instructions. To quantify the iridoviral DNA present in the homogenate, real-time PCR was performed using a LightCycler 480II (Roche) according to the manufacturer's instructions. The reaction mixture contained $1 \times$ Eva green dye, $1 \times$ PCR buffer $(10 \mathrm{mM}$ Tris- $\mathrm{HCl}[\mathrm{pH} 8.3], 50 \mathrm{mM} \mathrm{KCl}), 2.5 \mathrm{mM} \mathrm{MgCl}_{2}, 0.3 \mathrm{mM}$ dNTPs, $0.5 \mathrm{pM}$ of each primer, $2.5 \mathrm{U}$ of Taq DNA polymerase, and $1 \mu \mathrm{g}$ of template DNA in a total volume of $20 \mu$ l. The amplification conditions were as follows: $94^{\circ} \mathrm{C}$ for $10 \mathrm{~min}$, followed by 40 cycles of $94^{\circ} \mathrm{C}$ for $10 \mathrm{~s}$, $52^{\circ} \mathrm{C}$ for $15 \mathrm{~s}$, and $72^{\circ} \mathrm{C}$ for $20 \mathrm{~s}$. No evidence of nonspecific amplification was observed. As a positive control, recombinant plasmid TOPO-TA containing $163 \mathrm{bp}$ from the major capsid protein gene, amplified using the primers MC1F (5'-GAG GTG CGC ATC CAC TTC-3') and MC1R (5'-CAA GAT GAT TGG CAT GCG-3'), was purified from transformed Escherichia coli DH5. A serial 10-fold dilution of the control plasmid was used to establish a standard curve $\left(5.0 \times 10^{9}\right.$ to $5.0 \times 10^{1}$ copies $\left.\mu^{-1}\right)$. The standard curve, generated using the mean data from experiments performed in triplicate, indicated a good linear relationship between the $C_{\mathrm{T}}$ values and the logarithmic plasmid concentrations ranging from $7.0 \times 10^{1}$ to $7.0 \times 10^{9}$ copies (data not shown).

\section{RESULTS}

\section{Effect of water temperature on mortality}

Following inoculation the mean number $(17,20$, and 30) of days until death of the infected rock bream Oplegnathus fasciatus at 25,21 , and $18^{\circ} \mathrm{C}$, respectively, was inversely proportional to water temperature. The time pe- 
riods to reach $100 \%$ cumulative mortality from the appearance of the first dead fish, i.e. the rates of mortality, at the 3 water temperatures ranged from 10 to $15 \mathrm{~d}$ (Fig. 1). PCR-positive results and typical histopathology (enlarged cells) were observed in the spleen imprints from all dead fish, with the exception of 2 of 3 rock bream that died and were sampled $24 \mathrm{~d}$ post-injection in the group held at $18^{\circ} \mathrm{C}$. The rock bream injected with IVS-1 and kept at $13^{\circ} \mathrm{C}$ for $45 \mathrm{~d}$ after injection did not show any clinical signs or primary PCR-positive results, and no deaths were recorded. However, viral DNA was detected in nested PCR throughout the experimental period in all fish held at $13^{\circ} \mathrm{C}$. Quantitative PCR data revealed that the viral copy numbers in the spleens of rock bream held at $13^{\circ} \mathrm{C}$ for $45 \mathrm{~d}$ were slightly higher than those of fish held for only $3 \mathrm{~d}$. Viral concentration in the tissue of the infected rock bream increased rapidly at $25^{\circ} \mathrm{C}$ and appeared to be sufficient to give a weak positive result in primary PCR even after $3 \mathrm{~d}$. Comparison of the viral copy numbers present in spleens of the dead rock bream infected at 25, 21, and $18^{\circ} \mathrm{C}$ revealed that viral copy numbers were inversely proportional to temperature. However, the decreased ratio of the copy numbers between the groups at 21 and $18^{\circ} \mathrm{C}$ was more dramatic than that found between 25 and $21^{\circ} \mathrm{C}$ (Tables 2 \& 3). No dead fish were observed in control groups injected with PBS at the 4 different temperatures.

\section{Influence of temperature shifts after infection with IVS-1 on the mortality of rock bream}

The water temperature was shifted up to $25^{\circ} \mathrm{C}, 7,14$, or $30 \mathrm{~d}$ after the injection of IVS-1 in rock bream at $13^{\circ} \mathrm{C}_{i}$ this temperature shift to $25^{\circ} \mathrm{C}$ induced $100 \%$ cumulative mortality in all groups of fish (Fig. 2). The mean number of days until death was calculated using the day of the temperature shift as the first day of infection and was not influenced significantly by the holding periods of the virusinjected fish at $13^{\circ} \mathrm{C}$ before shifting to $25^{\circ} \mathrm{C}$, which is similar to the results for the positive control held at a constant temperature of $25^{\circ} \mathrm{C}$ after injection.

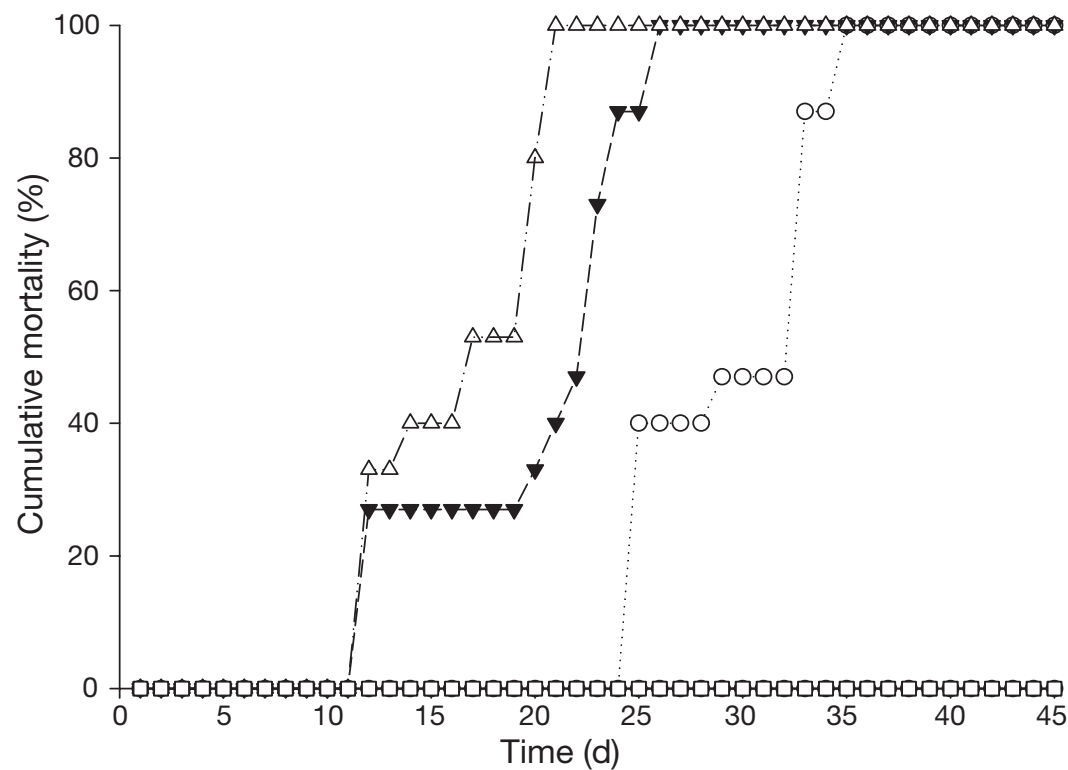

Fig. 1. Oplegnathus fasciatus. Cumulative mortality of IVS-1-infected rock bream at 4 different water temperatures. A splenic homogenate from iridovirusinfected fish was injected intramuscularly, and the fish were subsequently maintained at either $13^{\circ} \mathrm{C}(\bullet), 18^{\circ} \mathrm{C}(0), 21^{\circ} \mathrm{C}(\boldsymbol{\nabla})$, or $25^{\circ} \mathrm{C}(\Delta)$. Negative control rock bream were injected with PBS and were maintained at either $13^{\circ} \mathrm{C}(\boldsymbol{\square})$ or $25^{\circ} \mathrm{C}$ (). Three symbols for $13^{\circ} \mathrm{C}(\bullet)$ and negative controls ( $\square$ and $\square$ ) overlap and appear as a single symbol ( $\square$ ) on the $X$-axis

Table 2. Oplegnathus fasciatus. Infection status and viral load in the spleen of IVS-1-infected rock bream at 4 different water temperatures. Mean number of days until death was calculated as the sum of the number of days until death for individual fish in a group divided by the total number of dead fish in the group. Viral genome copies are given per milligram tissue of dead fish. Negative controls received an equivalent volume of sterile PBS via intramuscular injection. NA: not applicable; ND: not determined; SD: standard deviation, determined from 3 dead fish collected sequentially from the last dead fish

\begin{tabular}{|lccccc|}
\hline $\begin{array}{l}\text { Water } \\
\text { temperature } \\
\left({ }^{\circ} \mathrm{C}\right)\end{array}$ & $\begin{array}{c}\text { Primary } \\
\text { PCR }\end{array}$ & $\begin{array}{c}\text { Nested } \\
\text { PCR }\end{array}$ & $\begin{array}{c}\text { Mean no. } \\
\text { of days } \\
\text { until death }\end{array}$ & $\begin{array}{c}\text { Mean } C_{\mathrm{T}} \\
( \pm \mathrm{SD})\end{array}$ & $\begin{array}{c}\text { Viral genome } \\
\text { copies }( \pm \mathrm{SD})\end{array}$ \\
\hline 13 & - & + & $\mathrm{NA}$ & $\mathrm{NA}$ & $\mathrm{NA}$ \\
18 & + & $\mathrm{ND}$ & 30 & $11.9( \pm 0.7)$ & $6.7( \pm 1.6) \times 10^{6}$ \\
21 & + & $\mathrm{ND}$ & 20 & $8.8( \pm 0.7)$ & $5.8( \pm 2.3) \times 10^{7}$ \\
25 & + & ND & 17 & $7.0( \pm 0.4)$ & $2.1( \pm 0.9) \times 10^{8}$ \\
Negative & - & - & NA & NA & NA \\
$\begin{array}{l}\text { control }\left(13^{\circ} \mathrm{C}\right) \\
\text { Negative }\end{array}$ & - & - & NA & NA & NA \\
control $\left(25^{\circ} \mathrm{C}\right)$ & & & & & \\
\hline
\end{tabular}

However, the experimental group that was maintained for a longer period at $13^{\circ} \mathrm{C}$ before shifting to $25^{\circ} \mathrm{C}$ showed higher viral concentrations in the tissues of the rock bream analyzed by Q-PCR $3 \mathrm{~d}$ after the shift in temperature to $25^{\circ} \mathrm{C}$ (Table 3 ). These results were comparable to the increased viral copy numbers in the tissues of the rock bream held at $13^{\circ} \mathrm{C}$ after an extended incubation period of $45 \mathrm{~d}$, and may support the occurrence of replication in rock bream held at $13^{\circ} \mathrm{C}$ (Table 3 ). 


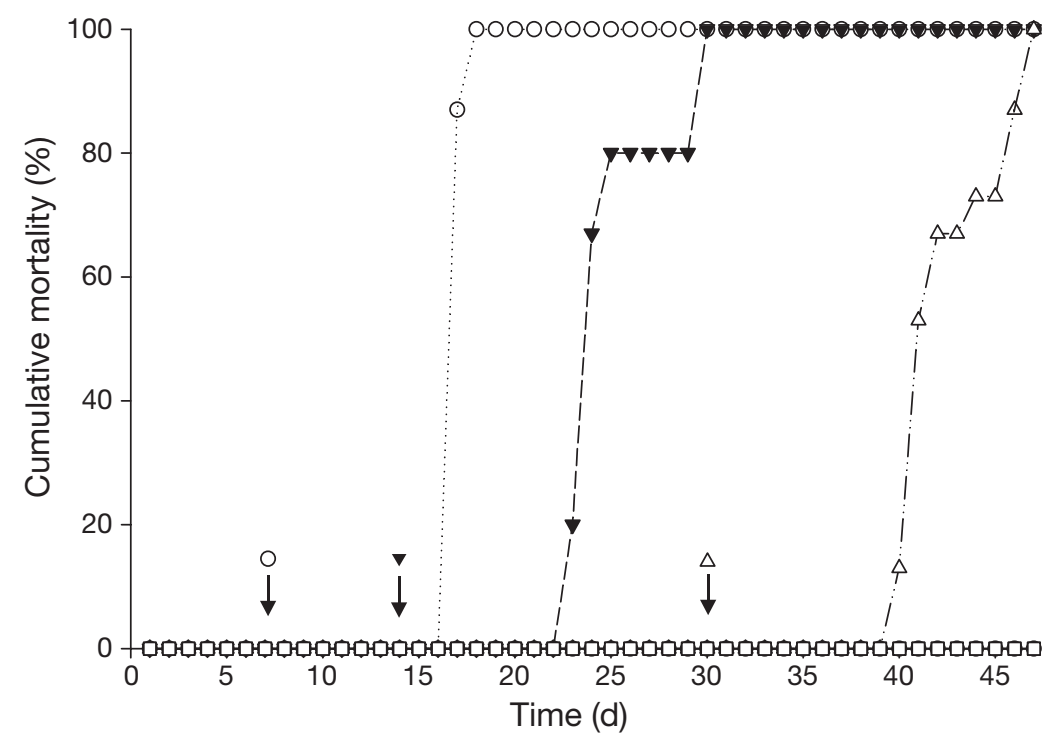

Fig. 2. Oplegnathus fasciatus. Effects of temperature shift from 13 to $25^{\circ} \mathrm{C}$ on the mortality of rock bream following injection of IVS-1 at $13^{\circ} \mathrm{C}$. Water temperature was shifted $7(\mathrm{O}), 14(\boldsymbol{\nabla})$, or $30(\Delta) \mathrm{d}$ post-injection at $13^{\circ} \mathrm{C}$. Arrows indicate the time at which the temperature was shifted. Rock bream were also injected with IVS-1 as a positive control group at $13^{\circ} \mathrm{C}(\bullet)$. Rock bream with temperature shifted to $25^{\circ} \mathrm{C} 0(\square)$ or $7(\square) \mathrm{d}$ post-injection of PBS at $13^{\circ} \mathrm{C}$ were used as negative controls. Three symbols for negative controls $(\bullet, \mathbf{\square}$, and $\square)$ overlap and appear as a single symbol $(\square)$ on the $x$-axis
The reverse experiment involved shifting the water temperature down (Fig. 3). Two groups of rock bream were shifted to $13^{\circ} \mathrm{C} 3$ and $7 \mathrm{~d}$ after injection of IVS-1 at $25^{\circ} \mathrm{C}$, and started to die 38 and $22 \mathrm{~d}$ after the temperature shift, respectively, and eventually showed $100 \%$ cumulative mortality with the mean number of days until death of 19 and $12 \mathrm{~d}$, respectively. These results were supported by Q-PCR data, showing increased viral concentrations in the spleens of both groups of rock bream, even after the temperature shift down to $13^{\circ} \mathrm{C}$ (Table 3). However, the viral copy numbers from the spleens of the dead fish at $13^{\circ} \mathrm{C}$, whether the temperature was shifted down to $13^{\circ} \mathrm{C} 3$ or $7 \mathrm{~d}$ after inoculation at $25^{\circ} \mathrm{C}$, were approximately one-hundredth of that found in the rock bream held at a constant temperature of $25^{\circ} \mathrm{C}$. Of the rock bream held at a constant temperature of $25^{\circ} \mathrm{C}, 100 \%$ died between 12 and $14 \mathrm{~d}$ post-injection. No mortality was observed among the virus-exposed rock bream

Table 3. Oplegnathus fasciatus. Effect of temperature shift on mortality and subsequent viral assays. Mean number of days until death was calculated as the sum of the number of days until death for individual fish in a group divided by the total number of dead fish in the group. Means of the viral genome copies are given per milligram of positive sample. NA: not applicable; ND: not determined

\begin{tabular}{|c|c|c|c|c|c|c|c|c|c|}
\hline $\begin{array}{l}\text { Initial } \\
\text { temperature } \\
\left({ }^{\circ} \mathrm{C} \text {, injection) }\right.\end{array}$ & $\begin{array}{l}\text { No. of days } \\
\text { held at initial } \\
\text { temperature }\end{array}$ & $\begin{array}{c}\text { Shifted water } \\
\text { temperature } \\
\left({ }^{\circ} \mathrm{C}\right)\end{array}$ & $\begin{array}{l}\text { No. of days } \\
\text { held at shifted } \\
\text { temperature }\end{array}$ & Deaths & $\begin{array}{l}\text { Mean no. } \\
\text { of days } \\
\text { until death }\end{array}$ & $\begin{array}{r}\text { PC } \\
\text { Primary }\end{array}$ & $\begin{array}{l}\text { CR } \\
\text { Nested }\end{array}$ & $\begin{array}{c}\text { Mean } C_{\mathrm{T}} \\
\quad( \pm \mathrm{SD})\end{array}$ & $\begin{array}{l}\text { Viral genome } \\
\text { copies }( \pm \mathrm{SD})\end{array}$ \\
\hline \multirow[t]{13}{*}{13} & 3 & No shift & NA & NA & NA & - & + & $29.0( \pm 0.7)$ & $1.7( \pm 0.5) \times 10^{2}$ \\
\hline & 7 & No shift & NA & NA & NA & - & + & $28.5( \pm 1.4)$ & $2.1( \pm 1.4) \times 10^{2}$ \\
\hline & 14 & No shift & NA & NA & NA & - & + & $24.4( \pm 0.7)$ & $1.9( \pm 0.3) \times 10^{3}$ \\
\hline & 45 & No shift & NA & $0 / 15$ & NA & - & + & $22.8( \pm 0.8)$ & $4.2( \pm 2.1) \times 10^{3}$ \\
\hline & 7 & 25 & 3 & $0 / 15$ & NA & + & ND & $17.7( \pm 0.3)$ & $1.1( \pm 2.3) \times 10^{5}$ \\
\hline & & & 7 & $0 / 15$ & NA & + & ND & $8.9( \pm 0.5)$ & $5.4( \pm 1.8) \times 10^{7}$ \\
\hline & & & Dead & $15 / 15$ & 10 & + & ND & $7.7( \pm 0.5)$ & $1.3( \pm 4.6) \times 10^{8}$ \\
\hline & 14 & 25 & 3 & $0 / 15$ & NA & + & ND & $11.2( \pm 0.4)$ & $1.1( \pm 3.5) \times 10^{7}$ \\
\hline & & & 7 & $0 / 15$ & NA & + & ND & $7.8( \pm 0.8)$ & $1.2( \pm 0.7) \times 10^{8}$ \\
\hline & & & Dead & $15 / 15$ & 8 & + & ND & $7.1( \pm 1.2)$ & $1.9( \pm 0.6) \times 10^{8}$ \\
\hline & 30 & 25 & 3 & $0 / 15$ & NA & + & ND & $8.9( \pm 0.5)$ & $5.5( \pm 1.7) \times 10^{7}$ \\
\hline & & & 7 & $0 / 15$ & NA & + & ND & $7.6( \pm 0.4)$ & $1.4( \pm 2.0) \times 10^{8}$ \\
\hline & & & Dead & $15 / 15$ & 13 & + & ND & $6.7( \pm 1.4)$ & $2.7( \pm 0.4) \times 10^{8}$ \\
\hline \multirow[t]{11}{*}{25} & 3 & No shift & NA & $0 / 15$ & NA & $+^{\mathrm{a}}$ & ND & $19.9( \pm 0.5)$ & $2.5( \pm 0.8) \times 10^{4}$ \\
\hline & 7 & No shift & NA & $0 / 15$ & NA & + & ND & $9.5( \pm 0.5)$ & $3.7( \pm 1.4) \times 10^{7}$ \\
\hline & Dead & No shift & NA & $15 / 15$ & 13 & + & ND & $5.1( \pm 0.8)$ & $1.0( \pm 1.1) \times 10^{9}$ \\
\hline & 3 & 13 & 3 & $0 / 15$ & NA & + & ND & $18.2( \pm 0.7)$ & $8.0( \pm 1.4) \times 10^{4}$ \\
\hline & & & 7 & $0 / 15$ & NA & + & ND & $17.1( \pm 0.5)$ & $1.7( \pm 0.7) \times 10^{5}$ \\
\hline & & & 14 & $0 / 15$ & NA & + & ND & $15.5( \pm 0.7)$ & $5.4( \pm 2.1) \times 10^{5}$ \\
\hline & & & Dead & $15 / 15$ & 50 & + & ND & $10.0( \pm 0.3)$ & $2.5( \pm 0.7) \times 10^{7}$ \\
\hline & 7 & 13 & 3 & $0 / 15$ & NA & + & ND & $11.9( \pm 0.5)$ & $6.4( \pm 1.0) \times 10^{6}$ \\
\hline & & & 7 & $0 / 15$ & NA & + & ND & $9.7( \pm 0.8)$ & $3.2( \pm 1.9) \times 10^{7}$ \\
\hline & & & 14 & $0 / 15$ & NA & + & ND & $9.7( \pm 0.9)$ & $3.4( \pm 1.9) \times 10^{7}$ \\
\hline & & & Dead & $15 / 15$ & 29 & + & ND & $8.6( \pm 1.0)$ & $6.5( \pm 0.8) \times 10^{7}$ \\
\hline${ }^{\mathrm{a}} \mathrm{A}$ weak band & & & & & & & & & \\
\hline
\end{tabular}




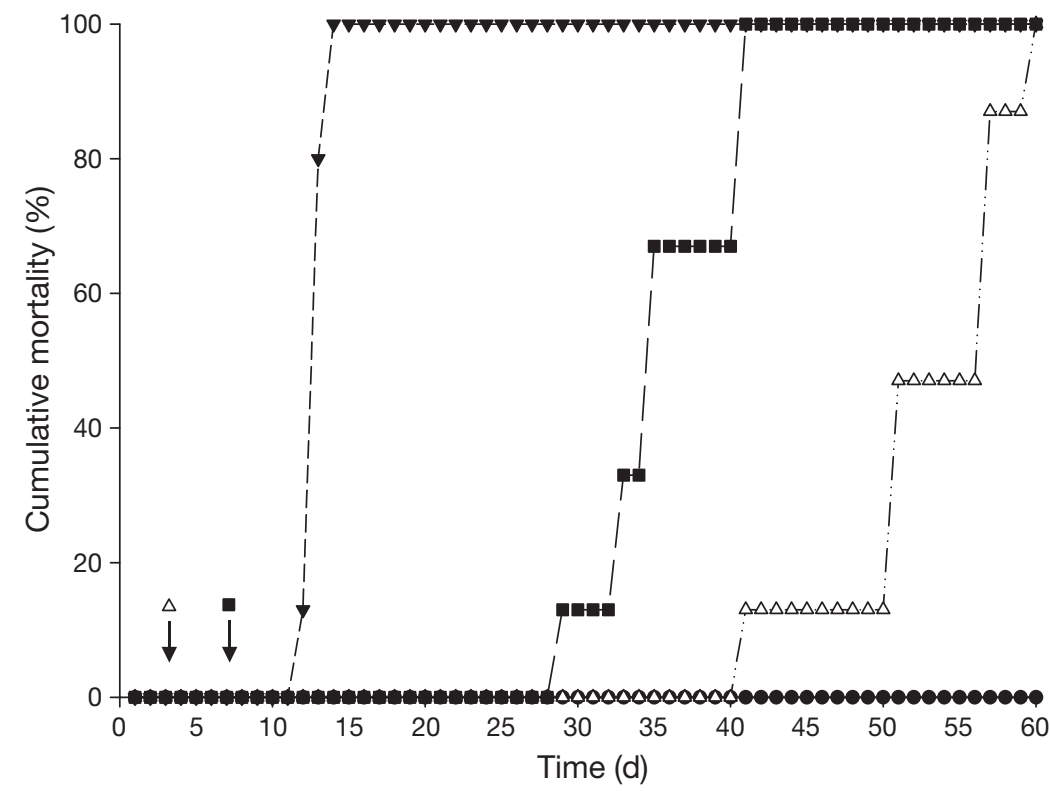

Fig. 3. Oplegnathus fasciatus. Effects of temperature shift from 25 to $13^{\circ} \mathrm{C}$ on the mortality of rock bream following IVS-1 infection at $25^{\circ} \mathrm{C}$. Water temperature was shifted $3(\Delta)$ or $7(\mathbb{\square})$ d post-injection at $25^{\circ} \mathrm{C}$. Arrows indicate the time at which the temperature was shifted. Rock bream were also injected with IVS-1 as a positive control at $25^{\circ} \mathrm{C}(\boldsymbol{\nabla})$. Rock bream with temperature shifted to $13^{\circ} \mathrm{C} 0(\bullet)$ or $3(0) \mathrm{d}$ post-injection of PBS at $25^{\circ} \mathrm{C}$ were used as negative controls. Two symbols for negative controls ( and O) overlap and appear as a single symbol $(\bullet)$ on the $x$-axis

held at a constant temperature of $13^{\circ} \mathrm{C}$ until $60 \mathrm{~d}$ after injection (Fig. 3). Neither was mortality observed in the control groups that were not exposed to IVS-1, regardless of whether they were held at a constant water temperature or shifted up or down between 13 and $25^{\circ} \mathrm{C}$.

\section{DISCUSSION}

Viral infections in ectothermic vertebrates can be influenced greatly by temperature (Ahne et al. 2002). Water temperature influences the onset and severity of fish virus infections by directly altering viral replication and by indirectly augmenting the efficacy of the host immune response (Alcorn et al. 2002, Bly \& Clem 1992). Although iridovirus, genus Megalocytivirus, is the most significant fish pathogen in cultured rock bream Oplegnathus fasciatus found in Asian countries, including Korea, little information is available concerning the cumulative mortality at different water temperatures after viral infection. Recently, when mandarinfish Siniperca chuatsi were infected experimentally with ISKNV and held at 20 or $15^{\circ} \mathrm{C}$, no clinical signs or mortality were observed over the $30 \mathrm{~d}$ experimental period (He et al. 2002). At temperatures $>25^{\circ} \mathrm{C}$, clinical signs and high mortality were observed, with the average time until death being 10 to $15 \mathrm{~d}$.
Little information is available regarding the influence of water temperature on RSIV replication, on the progression of the disease, or on the viral concentrations in the tissues of infected fish. RSIV is the most common strain of iridovirus showing seasonal variations in temperature in fish cultured in seawater.

An in vitro analysis conducted in Japan revealed that the optimal temperature range for RSIV replication in bluegill fibroblast (BF-2) cells ranged between 15 and $30^{\circ} \mathrm{C}$ (Nakajima \& Sorimachi 1994). In that study, the viral titers obtained at $15,20,25$, and $30^{\circ} \mathrm{C}$ were similar, even though viral replication at 15 and $30^{\circ} \mathrm{C}$ was slower than that at 20 and $25^{\circ} \mathrm{C}$ (Nakajima \& Sorimachi 1994).

In the present study, the values of the mean number of days until death demonstrated that all rock bream infected at 25 , 21 , and $18^{\circ} \mathrm{C}$ died with a slower progression of the disease at lower water temperatures: $12 \mathrm{~d}$ at both 25 and $21^{\circ} \mathrm{C}$ and $25 \mathrm{~d}$ at $18^{\circ} \mathrm{C}$, but no mortality with any histopathological signs was observed at $13^{\circ} \mathrm{C}$ over the $45 \mathrm{~d}$ experimental period (Fig. 1). Our weak, positive primary PCR result after $3 \mathrm{~d}$ at $25^{\circ} \mathrm{C}$ is similar to that reported by Chao \& Yang (2002), where positive results were obtained after $2 \mathrm{~d}$ of infection. The results are consistent with the observed natural outbreaks of iridoviral disease in rock bream, which only occur from June to November at water temperatures ranging from 18 to $29^{\circ} \mathrm{C}$ on the coast of Korea. However, we detected lower viral copy numbers in the tissues of fish that died at lower water temperatures. This result suggests that lower viral numbers can cause iridoviral disease in rock bream at lower water temperatures, possibly due to the suppressed defense system of the fish. As an additional remark, the quantified viral genome copies in the spleens of rock bream that died after being held at a constant temperature of $25^{\circ} \mathrm{C}$ after inoculation were much higher, compared to those of largemouth bass Micropterus salmoides salmoides and large yellow croaker Pseudosciaena crocea infected with largemouth bass virus (LMBV) and large yellow croaker iridovirus (LYCIV), respectively (Goldberg et al. 2003, Wang et al. 2006). However, it should be noted that differences in these studies, i.e. in vivo versus in vitro, target species of fish, and the strains of iridovirus used, are all factors that may influence the virus-host interaction. Additionally, for experiments performed in our laboratory, the use of serial subcultures of the iridovirus in the grunt fin (GF-2) cell line (which is 
known to support the growth of iridovirus) resulted in a loss of infectious virus; this occurred so quickly that we were unable to obtain accurate data for this experiment. Such a loss of infectivity was even more severe after culturing the iridovirus in the BF-2 cell line (data not shown). Establishment of a cell line from rock bream, the most susceptible fish species to iridovirus, may be needed for better replication of iridoviruses.

Infected fish held at $13^{\circ} \mathrm{C}$ did not die, even though viral DNA was detected by nested PCR throughout the experimental period. Moreover, using quantitative $\mathrm{PCR}$, we observed very slow replication, rather than clearance of iridovirus, in the tissue of rock bream held at $13^{\circ} \mathrm{C}$ (Table 3 ). Such increased viral concentration at the low level of infection in this experiment may not be sufficient to significantly change the mean number of days until death (Fig. 1).

The lack of clearance of viral particles in fish held at $13^{\circ} \mathrm{C}$ was confirmed by the observed mortality in the experiment when the temperature was shifted from 13 to $25^{\circ} \mathrm{C}$, even at $30 \mathrm{~d}$ post-injection at $13^{\circ} \mathrm{C}$ (Fig. 2). Failure of the rock bream to recover from viral infection at $13^{\circ} \mathrm{C}$ implies that the immune system of the animals was suppressed to such a degree that it could not eliminate the relatively low level of iridovirus at $13^{\circ} \mathrm{C}$. Thus, it is likely that rock bream, one of the most susceptible fish species to iridovirus, when exposed to a low dose of pathogenic iridovirus in early spring, may exhibit mortality even in early summer in marine aquatic farms with seawater temperatures of from 17 to $19^{\circ} \mathrm{C}$, with cases becoming more severe as temperature increases further over the summer. However, this must be differentiated from the subclinical infections that are found in many different fish species throughout the year, including fingerlings of rock bream. Most fingerling rock bream with such subclinical infections appear healthy and do not exhibit clinical signs even in the summer season, but have been diagnosed with subclinical infection in our laboratory.

Moreover, in our previous reports, 2 groups of externally healthy fish, consisting of market-size (200 g body weight) and 2-mo-old (20 g body weight) rock bream collected and confirmed as positive for IVS-1 in May by 2 -step PCR, did not show any mortalities over $18 \mathrm{~d}$ at $23^{\circ} \mathrm{C}$ (Jeong et al. 2006). ISKNV also showed similar infections in ornamental fish - either clinical with associated mortality (and positive in single-step PCR) or subclinical in healthy fish (only positive in 2step PCR) (Jeong et al. 2008). However, there is another report in which fingerling, but not yearling, rock bream infected subclinically by iridovirus showed high cumulative mortality $13 \mathrm{~d}$ after shifting the water temperature from 18 to $26^{\circ} \mathrm{C}$ (Choi et al. 2006). Currently, it is not fully understood why some subclinical iridoviral infections remain subclinical, while others progress to overt disease. It is possible that there is a complex interaction between viral load, the state of the host's immune system, and ambient temperature. Alternatively, in some subclinically infected fish, iridovirus may be present as truncated virus particles or as incompletely formed virions or other noninfective units, as has been suggested for infections involving hematopoietic necrosis virus (Drolet et al. 1995).

The fish used in the temperature shift-down experiments were initially held at $25^{\circ} \mathrm{C}$ for 3 or $7 \mathrm{~d}$ after infection (Fig. 3). These fish might be considered as groups exposed to high doses of virus at different levels. The clinical signs, a slightly enlarged spleen with hypertrophic cells with inclusion bodies, were already observed in the fish at $25^{\circ} \mathrm{C}$ after $7 \mathrm{~d}$, but not $3 \mathrm{~d}$ after inoculation. In the temperature shift-down experiments $\left(25\right.$ to $\left.13^{\circ} \mathrm{C}\right)$, it took much longer to reach $100 \%$ cumulative mortality than in fish held at a constant temperature of $25^{\circ} \mathrm{C}$. The viral concentrations in dead fish, which had been shifted down to $13^{\circ} \mathrm{C} 3$ or $7 \mathrm{~d}$ after injection of IVS- 1 at $25^{\circ} \mathrm{C}$, were similar, but not as high as the levels found in fish held at a constant temperature of $25^{\circ} \mathrm{C}$. These results are in agreement with those determined by Rojas et al. (2005), who reported a higher viral titer in virus-exposed salamanders Ambystoma tigrinum held at $10^{\circ} \mathrm{C}$ than those held at $18^{\circ} \mathrm{C}$, but low virus concentrations in the small number of salamanders that died at $26^{\circ} \mathrm{C}$.

In practical terms, and in contrast to SVC (Ahne 1986) and KHV diseases (Gilad et al. 2003), it is unlikely that temperature shifts could be used to control iridoviral disease. A temperature shift to $13^{\circ} \mathrm{C}>3 \mathrm{~d}$ after the injection of IVS-1 at $25^{\circ} \mathrm{C}$ induced a prolonged mean time until death compared to that of fish held at a constant temperature of $25^{\circ} \mathrm{C}$, but did not alleviate mortality of the rock bream (Fig. 3). Additionally, it would appear that the threshold of viral load for disease and mortality is on the order of $10^{7}$ to $10^{8}$ viral copies $\mathrm{mg}^{-1}$ tissue (Table 3 ), and temperature determines the speed at which this threshold is reached and, hence, the time until outbreak of the disease and mortality. Presumably, at $25^{\circ} \mathrm{C}$, viral replication is relatively rapid and is not arrested sufficiently by shifting to the water temperature to $13^{\circ} \mathrm{C}$, leaving the viral load to increase further to the lethal threshold. While $25^{\circ} \mathrm{C}$ may be the optimal temperature for rock bream physiology, it appears that viral replication occurs so rapidly at this temperature that it cannot be controlled by the fish's immune system. Further studies are required to determine the role, if any, of neutralizing antibodies following iridovirus infection of rock bream at relatively high temperatures, similar to the studies of SVC in which antibodies that were produced at temperatures $>20^{\circ} \mathrm{C}$ led to a rapid decline of the virus in the blood (Ahne 1986). 
In the present study, the low dose of iridovirus at low water temperature was not eliminated, and led to disease outbreaks, even after long incubation times, precipitated by increased water temperatures. Moreover, we found that, while decreasing the water temperature affected the peak levels of accumulated iridovirus in dead rock bream, it is unlikely to mitigate mortality by iridoviral disease in marine aquaculture. Thus, the observed mortalities in the temperature-shift experiments indicated that rock bream can carry iridovirus at low water temperatures without viral clearance for extended periods of time and may explain why this virus causes recurrent mass mortality in marine farms in Korea.

Acknowledgements. This work was supported by the Korea Research Foundation Grant funded by the Korean Government (KRF-2008-313-F00079).

\section{LITERATURE CITED}

Ahne W (1984) Important viral diseases in European fish cultures. Symp Biol Hung 23:3-15

> Ahne W (1986) The influence of environmental temperature and infection route on the immune response of carp (Cyprinus carpio) to spring viremia of carp virus. Vet Immunol Immunopathol 12:383-386

Ahne W, Bjorklund HV, Essbauer S, Fijan N, Kurath G, Winton JR (2002) Spring viremia of carp (SVC). Dis Aquat Org 52:261-272

Alcorn SW, Murray AL, Pascho RJ (2002) Effects of rearing temperature on immune functions in sockeye salmon (Oncorhynchus nerka). Fish Shellfish Immunol 12: 303-334

Bly JE, Clem LW (1992) Temperature and teleost immune functions. Fish Shellfish Immunol 2:159-171

Chao CB, Yang SC (2002) A nested PCR for the detection of grouper iridovirus in Taiwan (TGIV) in cultured hybrid grouper, giant seaperch, and largemouth bass. J Aquat Anim Health 14:104-113

> Chen XH, Lin KB, Wang XW (2003) Outbreaks of an iridovirus disease in maricultured large yellow croaker, Larimichthys crocea (Richardson), in China. J Fish Dis 26: 615-619

Chinchar G, Essbauer S, He JG, Hyatt A, Miyazaki T (2005) Family Iridoviridae. In: Fauquet CM, Mayo MA, Maniloff J, Desselberger U, Ball LA (eds) Virus taxonomy classification and nomenclature of viruses: 8th report of the international committee on the taxonomy of viruses. Academic Press, San Diego, CA, p 145-161

Choi SK, Kwon SR, Nam YK, Kim SK, Kim KH (2006) Organ distribution of red sea bream iridovirus (RSIV) DNA in asymptomatic yearling and fingerling rock bream (Oplegnathus fasciatus) and effects of water temperature on transition of RSIV into acute phase. Aquaculture 256:23-26

Cohen N (1966) Tissue transplantation immunity in the adult newt, Diemictylus iridescens. III. The effects of X-irradia-

Editorial responsibility: Mark Crane,

Geelong, Victoria, Australia tion and temperature on the allograft reaction. J Exp Zool 163:231-240

Do JW, Moon CH, Kim HJ, Ko MS and others (2004) Complete genomic DNA sequence of rock bream iridovirus. Virology 325:351-363

Drolet BS, Chiou PP, Heidel J, Leong JA (1995) Detection of truncated virus particles in a persistent RNA virus infection in vivo. J Virol 69:2140-2147

Gilad O, Yun S, Adkison MA, Way K, Willits NH, Bercovier H, Hedrick RP (2003) Molecular comparison of isolates of an emerging fish pathogen, koi herpesvirus, and the effect of water temperature on mortality of experimentally infected koi. J Gen Virol 84:2661-2668

Goldberg TL, Coleman DA, Grant EC, Inendino KR, Philipp DP (2003) Strain variation in an emerging iridovirus of warm-water fishes. J Virol 77:8812-8818

He JG, Deng M, Weng SP, Li Z and others (2001) Complete genome analysis of the mandarinfish infectious spleen and kidney necrosis iridovirus. Virology 291:126-139

> He JG, Zeng K, Weng SP, Chan SM (2002) Experimental transmission, pathogenicity and physical-chemical properties of infectious spleen and kidney necrosis virus (ISKNV). Aquaculture 204:11-24

Imajoh M, Ikawa T, Oshima SI (2007) Characterization of a new fibroblast cell line from a tail fin of red sea bream, Pagrus major, and phylogenetic relationships of a recent RSIV isolate in Japan. Virus Res 126:45-52

Jancovich JK (1999) Ambystoma tigrinum virus: identification, detection, transmission, characterization, and taxonomic position. MS thesis, Arizona State University, Tempe, AZ

> Jeong JB, Jun LJ, Yoo MH, Kim MS, Komisar JL, Jeong HD (2003) Characterization of the DNA nucleotide sequences in the genome of red sea bream iridoviruses isolated in Korea. Aquaculture 220:119-133

Jeong JB, Jun LJ, Park KY, Kim KH, Chung JK, Komisar JL, Jeong HD (2006) Asymptomatic iridovirus infection in various marine fishes detected by a 2-step PCR method. Aquaculture 255:30-38

Jeong JB, Kim HY, Jun LJ, Lyu JH, Park NG, Kim JK, Jeong HD (2008) Outbreaks and risks of infectious spleen and kidney necrosis virus disease in freshwater ornamental fishes. Dis Aquat Org 78:209-215

Jung SJ, Oh MJ (2000) Iridovirus-like infection associated with high mortalities of striped beakperch, Oplegnathus fasciatus (Temminck et Schlegel), in southern coastal areas of the Korean peninsula. J Fish Dis 23:223-226

Kawakami H, Nakajima K (2002) Cultured fish species affected by red sea bream iridoviral disease from 1996 to 2000. Fish Pathol 37:45-47

Lucas EA, Reynolds WA (1967) Temperature selection by amphibian larvae. Physiol Zool 40:159-171

Nakajima K, Sorimachi M (1994) Biological and physicochemical properties of the iridovirus isolated from cultured red sea bream. Fish Pathol 29:29-33

Rojas S, Richards K, Jancovich JK, Davidson EW (2005) Influence of temperature on Ranavirus infection in larval salamanders Ambystoma tigrinum. Dis Aquat Org 63: 95-100

> Wang XW, Ao JQ, Li QG, Chen XH (2006) Quantitative detection of a marine fish iridovirus isolated from large yellow croaker, Pseudosciaena crocea, using a molecular beacon. J Virol Methods 133:76-81

Submitted: August 29, 2008; Accepted: February 2, 2009

Proofs received from author(s): April 10, 2009 